\section{Database legislation}

ALA and its allies in the database legislative battles have continued to argue in favor of passage of H.R. 1858 and to fight H.R. 354.

These two database protection bills, which were introduced in 1999 in the House, are the subjects of renewed consideration and lively behind-the-scenes debate in the opening months of the Congress 2000. H.R. 354, the Collections of Information Antipiracy Act, has the support of some of the major commercial database publishers and the National Association of Realtors.

H.R. 354 provides overly broad protection for a "collection of information" that would reduce the public's access to information and unreasonably burden scientific research, scholarship, and education. H.R. 1858 is more narrowly focused to prevent the distribution of pirated databases, which could threaten a person's investment in database creation, but it does not prevent the reuse of information for the purpose of creating new innovative databases.

ACRL members are asked to contact their representatives and express the library community's support for H.R. 1858. Contact Miriam Nisbet at (800) 941-8478 for more information.

\section{International education funding}

The Coalition for International Education (of which ALA is a member) has asked the House and Senate Subcommittees on Labor, HHS and Education Appropriations for FY 2001 funding for HEA-Title VI and Fulbright-Hays 102(b)(6). ACRL members who are concerned about these two international programs are asked to contact the ALA Office for Government Relations to find out more about how to communicate examples of your roles with Title VI/F-H funding on your campuses.

Lynne E. Bradley is Office of Government Relations director of ALA's Washington Office; e-mail: leb@alawash.org

\section{Copyright rulemaking continues}

ALA, in partnership with the Association of Research Libraries, the American Association of Law Libraries, the Special Libraries Association, and the Medical Library Association, submitted comments to the Copyright Office regarding section 1201(a) of the Digital Millennium Copyright Act (DMCA) of 1998.

Because of concerns about the negative impact of this section on anticircumvention measures, Congress mandated that the Copyright office conduct a rulemaking study. Based on its findings, the Office will determine whether an exemption to the anticircumvention measure contained in Section 1201(a) should be allowed. Their recommendation will be forwarded to and considered by the Librarian of Congress. ALA and its sister library organizations have argued that an exemption should be allowed for libraries.

The libraries comments, along with the comments and responses of other stakeholders who support or oppose an exemption, can be found at the U.S. Copyright Office Web site, http://www.loc.gov/copyright/1201/anticirc.html

The Copyright Office will conduct public hearings to hear testimony from all interested parties. Librarians, computer scientists, and public interest groups, as well as representatives from the publishing, motion picture, recording, and software industries are expected to testify.

Hearings will be held on May 2-4, 2000, in Washington, D.C., in Room LA-202 of the John Adams Building of the Library of Congress, 110 Second Street, S.E. A second round of hearings will be held on May 18-19, 2000, at Stanford University in Room 290, Stanford Law School, Crown Quadrangle, Stanford, California.

After the hearings, the Copyright Office will accept additional comments from all interested parties before making its recommendation to the Librarian of Congress.

For more information, contact Carrie Russell, or Miriam Nisbet at the ALA Washington Office, (800) 941-8478. 
Libraries worldwide are talking about the OCLC Cooperative Online Resource Catalog (CORC) service. Using CORC, libraries select, describe, maintain and provide guided access to local and Web-based electronic resources for local users...while building pathways to unique information for global users.

CORC extends the successful OCLC WorldCat model of collaboration to electronic resources.

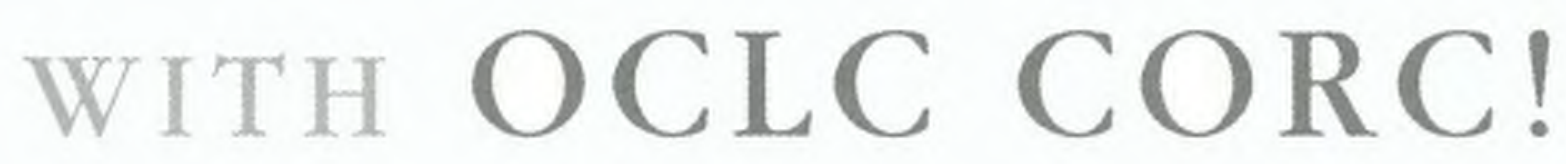

With CORC, libraries like yours:

- Integrate local, Web and non-electronic resources

- Save money through cooperation with other libraries and improved productivity

- Apply authority control to electronic resources

- Maintain record currency through URL maintenance tools

During the summer of 2000 , every library with an active OCLC cataloging authorization will gain access to CORC. To obtain an OCLC cataloging authorization, contact your OCLC or regional network representative, and discover how your library can join this new worldwide cooperative effort today.

Become your users' portal of choice by building locally and sharing globally...with the OCLC Cooperative Online Resource Catalog.

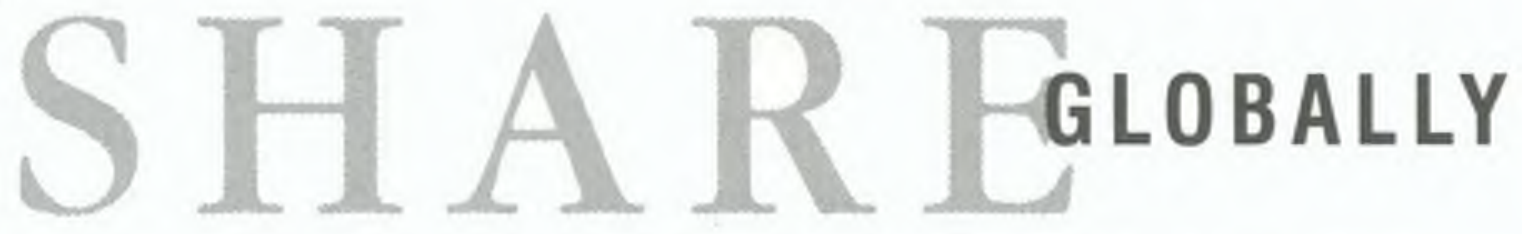
OCLC Online Computer Library Center, Inc. 1-800-848-5878, ext. 6251

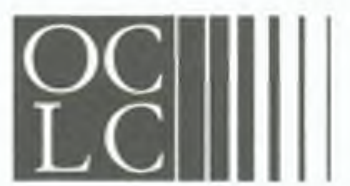
www.purl.oclc.org/corc

FURTHERING ACCESS TO THE WORLD'S INFORMATION 